\title{
Epidermal Growth Factor Receptor Tissue Expression Level as a Predictor for the Aggressiveness of HPV- associated Laryngeal Carcinoma
}

\author{
Thanaa Hamed, Mosad M. Odah, Eman A.E. Badr†, Ibrahiem Rageh*, \\ Abou-Bakr E. Ras** \& Magda H. Bakr*** \\ Departments of Medical Biochemistry, Clinical Pathology*, \\ Otorhinolaryngology** \& Pathology***, \\ Faculty of Medicine, Benha \& Minoufiya $\uparrow$ Universities
}

\begin{abstract}
This study was designed to evaluate the frequency of human papilloma virus (HPV) infection in patients with laryngeal squameous cell carcinoma (LSCC) through identification of the viral DNA using PCR analysis and to determine the tissue levels of epidermal growth factor receptor (EGFR) as a trial to find a relation between HPV infection, EGFR expression and clinicopathological findings in patients with LSCC. The study comprised 32 patients with suspected LSCC; 25 males and 7 females; with mean age 53.3 \pm 12.2 ; range: 25-72 years. All females and 5 males were non-smokers; while 20 males were smokers. Patients were subjected to full history taking and clinical examination. Direct laryngoscopy was performed under light general anesthesia in the operating room for evaluation of the larynx and the entire upper aerodigestive tract for accurate clinical staging according to TNM classification, to determine the full extent of the local spread of the tumor and to obtain tissue biopsy. Fresh tumor tissue specimens were divided into two parts, the first was studied and graded pathologically according to World Health Organization (WHO) classification and the second was stored at $-70^{\circ} \mathrm{C}$ until processed and examined by PCR technique for the presence of HPV-DNA and analyzed for EGFR expression expressed as femto$\mathrm{mol} / \mathrm{mg}(\mathrm{fM} / \mathrm{mg})$ protein. Squameous cell carcinoma was detected in 29 cases $(90.6 \%)$ and 3 cases were excluded off the study; 21 patients (72.4\%) had lesions clinically staged as stage I, while 3 (10.3\%) and 5 (17.3\%) had lesions of stages II and III, respectively. Patients had Stage I lesions were significantly $(p<0.05)$ younger than patients with stage II and III lesions and 9 lesions were detected in non-smokers. Laryngoscopy defined 23 (79.3\%) glottic lesions, 2 (6.9\%) supraglottic and 3 (10.3\%) subglottic lesions and one case (3.4\%) had an extensive squamous cell carcinoma of the larynx involving the subglottic region, the glottis and the supraglottic areas. There were 21 (72.4\%) polypoid lesions and 8 (27.6\%) ulcerative lesions. According to WHO classification, 14 specimens were type 1, 9 specimens type 2 and 6 specimens were type 3. PCR could detect HPV-DNA in 16 (55.2\%) specimens (viral specimens) and could not be detected in the other 13 specimens (non-viral cases). Four specimens of WHO type 1, 6 specimens of WHO type 2 and 6 specimens of WHO type 3 were viral specimens. Mean tissue expression level of EGFR was $37.7 \pm 32.2 \mathrm{fM} / \mathrm{mg}$ protein and was significantly higher in viral (54.7 $\pm 27.8 \mathrm{fM} / \mathrm{mg}$ protein) compared to
\end{abstract}


non-viral cases (16.8 $24.6 \mathrm{fM} / \mathrm{mg}$ protein) and in specimens of WHO type 2 and 3 compared to those of type 1. Moreover, there was a positive significant correlation between the pathological WHO types and presence of viral infection, $(r=0.568$, $p=0.001)$ and the tissue expression levels of EGFR, $(r=0.720, p<0.001)$ and $a$ positive significant correlation between tissue expression of EGFR and the presence of viral infection, $(r=0.595, P=0.001)$. Using the receiver operating characteristic (ROC) curve analysis judged by the area under the curve (AUC) to determine the specificity of the presence of HPV infection and tissue expression of EGFR as a predictor of cancer aggressiveness manifested as WHO pathological stage revealed that tissue expression of EGFR is more specific $(A U C=0.731)$ than the presence of viral infection (AUC=0.583). It could be concluded that laryngeal infection with HPV may predispose to carcinogenesis through activation of certain growth factors as EGF and both were found significantly correlated with the aggressiveness of LSCC with the level of tissue expression of EGFR being a specific determinant of tumor aggressiveness manifested as pathologic stage.

\section{INTRODUCTION}

Head and neck squamous cell carcinoma (HNSCC) is the $6^{\text {th }}$ most common cancer worldwide. In 2005, 400,000 cases of HNSCC were diagnosed worldwide. Laryngeal carcinoma is the second most common type of head and neck cancer after skin cancer and accounts for 3\% of total cancer risk ${ }^{(1)}$.

Alcohol/tobacco consumption is the most important risk factor for that neoplasia; nevertheless, since 1983 it has been suggested that human papilloma viruses have a role in HNSCC, mainly in the oropharynx. In the last years, some authors showed the implication of the HPV in the development of pre-carcinogenic lesions and of squamous cell carcinoma ${ }^{(2)}$. The infection by HPV has been associated to hyperplastic epithelial lesions, papilloma and warty carcinoma in skin and in different types of mucosa, including the anusgenital, cervical, urethral, tracheobronchial, nasal, laryngeal and oral mucosa tracts. The viral high-risk geno-types (oncogenic) such as 16, $18,31,33$ and 35 are frequently associated to leukoplakia and squamous carcinoma ${ }^{(3)}$.

Human papilloma virus is a small double-stranded DNA virus that is capable of infecting cutaneous and mucosal epithelium, resulting in a variety of pathological lesions ${ }^{(4)}$. Among the more than 100 different types of HPV identified, HPV16 is the most common high-risk virus. Its contribution to neoplastic progression is predominantly through the action of the viral oncoproteins E6 and E7. Expression of HPV16 E6 and E7 proteins is sufficient for the immortalization of primary human epithelial cells and induces histological abnormalities reminiscent of premalignant HPV-associated squameous intraepithelial lesions ${ }^{(5)}$.

According to the modern theory of carcinogenesis, a complex and multistep process is likely in the development of LSCC. Cancer is caused by uncontrolled proliferation of cells, which is itself induced by abnormalities of cell cycle regulatory 
mechanisms or activation of growth factors involved in cell proliferation and differentiation ${ }^{(6)}$. The p53 tumorsuppressor gene regulates cell cycle progression through induction of apoptosis at the $\mathrm{G} 1 / \mathrm{S}$ checkpoint. It has been well documented that E6 and E7 oncoproteins alter normal cell growth control mechanisms by inactivating two well-characterized tumor suppressor proteins, p53 and retinoblastoma protein, respectively ${ }^{(7)}$.

There is evidence that inherited differences in cell cycle control systems, DNA repair systems, and carcinogen-metabolizing enzymes or altered dominant and recessive oncogenes, genetic instability, and growth factor-linked signal transmission pathways could increase the risk for laryngeal cancer ${ }^{(8)}$. The transforming activity of high-risk HPV seems to depend primarily on deregulated expression of E6 and E7 HPV oncoproteins. The E5 HPV oncoprotein, also, seems to play a role in early growth stimulation of HPVinfected cells by an interaction with some cellular proteins, and in particular with growth factors receptors, and to alter the cell response to signals for growth and differentiation $^{(\mathbf{9})}$.

Epidermal growth factor receptor is composed of extracellular domains, including a ligand-binding domain, a hydrophobic transmembrane region and a tyrosine kinase-containing cytoplasmic region. Stimulation of the EGFR by endogenous ligands, EGF or transforming growth factor- $\alpha$ (TGF$\alpha$ ), results in a conformational change in the receptor, permitting it to enter into dimers and other oligomers. Dimerization results in activation of intracellular tyrosine kinase, protein phosphorylation and stimulation of various cell signaling pathways that mediate gene transcription and cell cycle progression $^{(\mathbf{1 0 )}}$. The EGFR is expressed on normal human cells but higher levels of expression of the receptor have, also, been shown to be correlated with malignancy in a variety of cancers. The activation of the EGFR participates in oncogenesis by inducing cell proliferation, cell mobility and angiogenesis, and inhibiting apoptosis. This activation might be due to numerous abnormalities, including increased expression of its ligand ${ }^{(11)}$.

The current study was designed to evaluate the frequency of HPV infection in patients with LSCC through identification of the viral DNA using PCR analysis and to determine the tissue levels of EGFR as a trial to find a relation between HPV infection, EGFR expression and clinicopathological findings in patients with LSCC.

\section{MATERIALS \& METHODS}

This prospective selective study was conducted at Departments of Otorhinolaryngology and Clinical Pathology, University hospital in conjunction with Medical Biochemistry and Pathology Departments, Faculty of Medicine, Benha and Minoufiya Universities. The study comprised 32 patients with suspected LSCC. They were 25 males $(78.1 \%)$ and 7 females $(21.9 \%)$ with mean age $53.3 \pm 12.2$; range: $25-72$ years. All females and 5 males were non-smokers; while the other 20 males were smokers. 
Patients were subjected to full history taking, clinical examination with respect to laryngeal region and underwent CT imaging. Direct laryngoscopy was performed under light general anesthesia in the operating room for evaluation of the larynx and the entire upper aerodigestive tract for accurate clinical staging, to determine the full extent of the local spread of the tumor and to obtain tissue biopsy. Cases were categorized clinically according to TNM classification ${ }^{(\mathbf{1 2})}$ and only cases with SCC were included in the study.

\section{Sample Preparation}

Fresh tumor tissue specimens were divided into two parts, the first was studied and graded pathologically according to the World Health Organization (WHO) classification, (13) and the second was kept frozen at $-70^{\circ} \mathrm{C}$ until processed and examined by PCR technique for the presence of HPV-DNA and analyzed for EGFR expression.

\section{A- Preparation of Cytosolic and Membrane Fractions}

Tumor specimens were finely minced and homogenized in 5 volumes of ice-cold buffer consisting of $25 \mathrm{mM}$ Tris, $1.5 \mathrm{mM}$ EDTA, $5 \mathrm{mM}$ NaN3, $0.1 \%$ monothiolglycerol, and 20\% glycerol using Plotter-Elvehjem homogenizer. The crude homogenate was centrifuged at $3000 \mathrm{revolve} / \mathrm{min}$ (rpm) for $20 \mathrm{~min}$ at $0^{\circ} \mathrm{C}$, and the supernatant was further centrifuged at $100 \mathrm{rpm}$ for $75 \mathrm{~min}$ at $0^{\circ} \mathrm{C}$ to obtain a cytosolic fraction for a membrane fraction for EGFR assay.

\section{EGFR Measurements}

The membrane pellet was resuspended in $25 \mathrm{mM}$ Tris, $1.5 \mathrm{mM}$
EDTA, $5 \mathrm{mM} \mathrm{NaN} \mathrm{N}_{3}, 20 \%$ glycerol, and $10 \mathrm{mM} \mathrm{MgCl}_{2}$. Aliquots of the suspension $(100 \mu \mathrm{l}$ containing 300 $500 \mu \mathrm{g}$ of protein) were incubated with ${ }^{125}$ I-EGF $\quad(2.6$ nM; 800,000 $\mathrm{Ci} / \mathrm{mmol}$; NEN, DuPont, Wilmington, $\mathrm{DE}$ ) for $12-16 \mathrm{~h}$ at room temperature in a final volume of $400 \mu \mathrm{l}$. Binding was blocked by the addition of $3 \mathrm{ml}$ of ice-cold $25 \mathrm{mM}$ Tris, $20 \%$ glycerol, 5 $\mathrm{mM} \mathrm{NaN} \mathrm{N}_{3}$, and $0.1 \%$ BSA. After centrifugation at $2000 \mathrm{rpm}$ for $20 \mathrm{~min}$ at $0^{\circ} \mathrm{C}$, the supernatant was carefully aspirated, and pellets were counted on Berthold Gamma Counter LB 2104 (Wallac, Inc., Gaithersburg, MD). Results were expressed as femto$\mathrm{mol} / \mathrm{mg} \quad(\mathrm{fM} / \mathrm{mg})$ protein. EGFR status was defined using the arbitrary cutoff value corresponding to the median value of EGFR levels, ${ }^{(14)}$.

\section{B- HPV DNA Extraction and}

\section{Detection}

a. DNA extraction using proteinase $\mathrm{K}$ in presence of $1 \%$ sodium dedoyl sulfate (SDS), phenol-chloroform and ethanol precipitation ${ }^{(\mathbf{1 5})}$.

b. PCR amplification:

Primer used: The primer pair MY11-MY09, supplied at concentration of $100 \mathrm{pmol} / \mathrm{ml}$ (Biometra, Germany); which were selected from a highly conserved region (L1) within the HPV genome $^{(\mathbf{1 6})}$. Amplification was carried out in a programmable Thermal Cycler 480 (Perkin Elmer, Norwalk, CY). An initial denaturation for $5 \mathrm{~min}$ at $94^{\circ} \mathrm{C}(1$ cycle) followed by $45 \mathrm{sec}$ at $95^{\circ} \mathrm{C}$, $45 \mathrm{sec}$ at $60^{\circ} \mathrm{C}, 60 \mathrm{sec}$ at $72^{\circ} \mathrm{C}(35$ cycles); then $10 \mathrm{~min}$ at $72^{\circ} \mathrm{C}(1$ cycle).

c. Electrophoretic separation and identification: An aliquot of 
amplified DNA was analyzed by $1.5 \%$ agarose gel electrophoresis, at constant current 100 volt for $45 \mathrm{~min}$ and ethidium bromide $(0.5 \mathrm{mg} / \mathrm{ml})$ staining to visualize fragments of the expected size (450 bp). Bands were visualized under ultraviolet illumination and photographed. The experiment was performed in parallel with a negative control in which PCR reaction was performed without a template DNA. To assess the integrity of the genomic DNA of HPV-negative samples, a region of the human $\beta$-globin gene was amplified as described previously, ${ }^{(15)}$. Negative controls included reaction mixtures lacking any DNA template and reaction mixtures containing human DNA without HPV target sequences. Procedures to prevent specimen contamination and PCR carryover were vigorously observed at every step in this analysis ${ }^{(\mathbf{1 7})}$.

\section{Statistical analysis}

Data were analyzed using t-test and Chi-square test. One-way ANOVA test was used to study variance of levels expression of EGFR. Possible relationships were investigated using Pearson linear regression. Specificity of the presence of HPV infection and tissue expression of EGFR as a predictor of cancer aggressiveness manifested as WHO pathological stage were evaluated using the receiver operating characteristic (ROC) curve analysis judged by the area under the curve (AUC). Statistical analysis was conducted using the SPSS (Version
10, 2002) for Windows statistical package. $\mathrm{P}$ value $<0.05$ was considered statistically significant.

\section{RESULTS}

Squameous cell carcinoma was detected in 29 cases $(90.6 \%)$ and 3 cases ( 2 males and one female) were excluded off the study; 2 cases with lymphoma and one case with spindle cell carcinoma. Twenty-one patients $(72.4 \%)$ had lesions clinically staged as stage I, while $3(10.3 \%)$ and 5 $(17.3 \%)$ had lesions of stages II and III, respectively. Patients had Stage I lesions were significantly $(\mathrm{p}<0.05)$ younger than patients with stage II and III lesions with a non-significant $(p>0.05)$ difference between patients staged II and III. One female patient had lesion of stage III, but the other 5 female patients had lesions of stage I, all other patients were males. Nine lesions were detected in non-smokers; one stage II and another of stage III; whereas the other 7 had stage I lesions. Laryngoscopy detected 23 (79.3\%) glottic lesions (18, 2 \& 3, according to stage respectively), 2 $(6.9 \%)$ supraglottic and $3(10.3 \%)$ subglottic lesions. One case (3.4\%) had an extensive squamous cell carcinoma of the larynx with the tumor involving the subglottic region, the glottis and the supraglottic areas. There were $21 \quad(72.4 \%)$ polypoid lesions, (19, $1 \& 1$ according to stage, respectively) and $8(27.6 \%)$ ulcerative lesions; 2, $2 \& 4$ according to stage, respectively, (Table 1). 
Table (1): Patients' distribution according to lesion character

\begin{tabular}{|c|c|c|c|c|c|}
\hline & Total & Stage I & Stage II & Stage III \\
\hline \multicolumn{2}{|l|}{ Number } & 29 & $21(72.4 \%)$ & $3(10.3 \%)$ & $5(17.3 \%)$ \\
\hline \multicolumn{2}{|c|}{ Age (years) } & $\begin{array}{c}51.9 \pm 13.2 \\
(25-72)\end{array}$ & $\begin{array}{c}46.6 \pm 11.5 \\
(25-63)\end{array}$ & $\begin{array}{c}65.3 \pm 5.8^{*} \\
(62-72)\end{array}$ & $\begin{array}{c}66.2 \pm 1.6^{*} \\
(65-68)\end{array}$ \\
\hline \multicolumn{2}{|l|}{ Sex; M:F } & $23: 6$ & $16: 5$ & $3: 0$ & $4: 1$ \\
\hline \multicolumn{2}{|c|}{ Smoker: Non-smokers } & $20: 9$ & $14: 7$ & $2: 1$ & $4: 1$ \\
\hline \multirow[t]{4}{*}{ Site } & Supraglottic & $2(6.9 \%)$ & 1 & 1 & 0 \\
\hline & Glottic & $23(79.3 \%)$ & 18 & 2 & 3 \\
\hline & Subglottic & $3(10.3 \%)$ & 2 & 0 & 1 \\
\hline & All site & $1(3.5 \%)$ & 0 & 0 & 1 \\
\hline \multirow[t]{2}{*}{ Character } & Polypoid & $21(72.4 \%)$ & 19 & 1 & 1 \\
\hline & Ulcerative & $8(27.6 \%)$ & 2 & 2 & 4 \\
\hline
\end{tabular}

Data are presented as mean $\pm \mathrm{SD}$, ratios \& numbers; ranges \& percentage in parenthesis

*: Significant difference versus stage I

According to WHO grading classification, histopathological examination of the 29 biopsies taken revealed the presence of 14 specimens WHO type 1, 9 specimens of WHO type 2 and 6 specimens WHO type 3, (Table 2). There was a non-significant difference between clinical staging and histopathological grading, $\left(\mathrm{X}^{2}=2.1, \mathrm{p}>0.05\right)$.

Table (2): Clinical and histopathological categorization of cases of laryngeal carcinoma

\begin{tabular}{|l|l|l|c|}
\hline \multicolumn{2}{|c|}{ Clinical staging } & \multicolumn{2}{c|}{ Histopathological typing } \\
\hline Stage I $\left(\mathrm{T}_{1} \mathrm{~N}_{0} \mathrm{M}_{0}\right)$ & $20(71.9 \%)$ & $\begin{array}{l}\text { WHO type 1 (squamous cell } \\
\text { carcinoma) }\end{array}$ & $14(48.3 \%)$ \\
\hline Stage II $\left(\mathrm{T}_{2} \mathrm{~N}_{0} \mathrm{M}_{0}\right)$ & $4(12.5 \%)$ & $\begin{array}{l}\text { WHO type 2 (non- } \\
\text { keratinizing carcinoma) }\end{array}$ & $9(31 \%)$ \\
\hline Stage III $\left(\mathrm{T}_{3} \mathrm{~N}_{0} \mathrm{M}_{0}-\mathrm{T}_{1-3}, \mathrm{~N}_{1} \mathrm{M}_{0}\right)$ & $5(15.6 \%)$ & $\begin{array}{l}\text { WHO type 3 } \\
\text { (undifferentiated carcinoma) }\end{array}$ & $6(20.7 \%)$ \\
\hline
\end{tabular}

T1: Tumor limited to normally mobile vocal cords (involving anterior and/or posterior commissure)

T2: Tumor extending to the supraglottis or subglottis with impaired vocal cord mobility

T3: Tumor confined to the larynx with vocal cord fixation

T4: Tumor invading through thyroid cartilage and/or with direct extralaryngeal spread N0: No lymph nodes (LN)

N1: Metastases to 1 ipsilateral cervical $\mathrm{LN} \leq 3 \mathrm{~cm}$ in greatest dimension

N2: Metastases to a single ipsilateral cervical $\mathrm{LN}>3 \mathrm{~cm}$ but $<6 \mathrm{~cm}$ in greatest dimension

N3: Metastasis in lymph node $>6 \mathrm{~cm}$

M0: no distant metastases.

M1: distant metastasis 
PCR detected HPV-DNA, (Fig. $1)$ in $16(55.2 \%)$ specimens (viral specimens) and were not detected in the other 13 specimens (non-viral cases). Four specimens of WHO type 1, 6 specimens of WHO type 2 and 6 specimens of WHO type 3 were viral specimens, (Table 3). Mean tissue expression levels of EGFR was $37.7 \pm 32.2$; range: $3-98 \mathrm{fM} / \mathrm{mg}$ protein. The mean level of EGFR in viral cases was $54.7 \pm 27.8$; range: 10 $98 \mathrm{fM} / \mathrm{mg}$ protein with a significant
$(\mathrm{P}<0.05)$ increase in comparison to non-viral cases that had a mean level of $16.8 \pm 24.6$; range: $3-78 \mathrm{fM} / \mathrm{mg}$ protein. There was increased tissue expression levels of EGFR in viral cases of all grades but showed a significant $(\mathrm{P}<0.05)$ increase in specimens of WHO type 2 and 3 compared to those of type 1 with a non-significant increase in specimens of WHO type 3 compared to those of type 2, (Table 3, Fig. 2).

$\begin{array}{llllllllllllllllllllll}M & 1 & 2 & 3 & 4 & 5 & 6 & 7 & 8 & 9 & 10 & 11 & 12 & 13 & 14 & 15 & 16 & 17 & 18 & 19 & 20 & \mathrm{C}-\mathrm{C}+\mathrm{M}\end{array}$

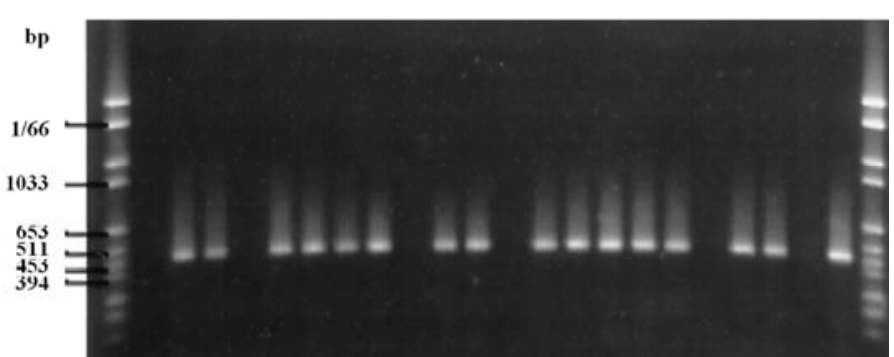

Fig. (1): Agarose gel electrophoresis of the PCR product a DNA-positive LSCC specimen. M: molecular weight marker VI (Boehringer Mannheim), $C+$ and $C$-, positive and negative PCR controls, respectively. Lanes 1, 4, 9, 12, and 18 are negative specimens; Lanes 2, 3, 5-8, 10, 11, 13-17, 19, and 20 are positive specimens

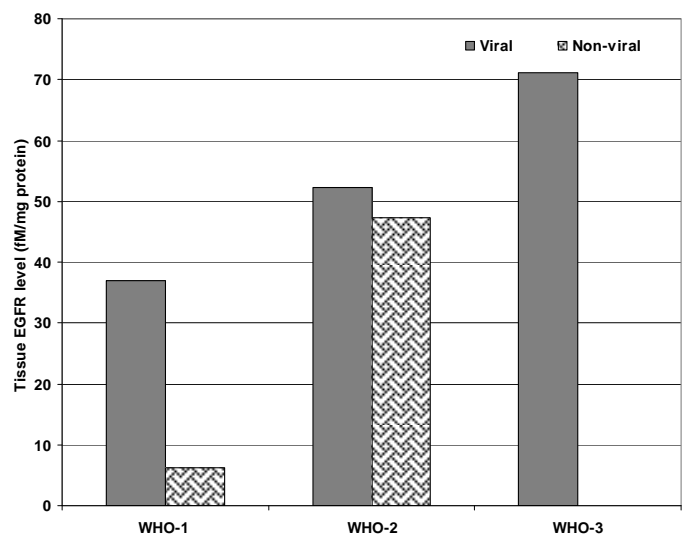

Fig. (2): Mean tissue expression of EGFR in specimens categorized according to WHO type and presence of HPV 
Table (3): Patients distribution according to HPV DNA detection and level of tissue expression of EGFR level in relation to WHO pathological types

\begin{tabular}{|c|c|c|c|c|c|}
\hline \multicolumn{2}{|l|}{ Data } & Total & $\begin{array}{l}\text { WHO } \\
\text { type1 }\end{array}$ & $\begin{array}{c}\text { WHO type } \\
2\end{array}$ & $\begin{array}{c}\text { WHO type } \\
3\end{array}$ \\
\hline \multicolumn{2}{|l|}{ Number } & 29 & 14 & 9 & 6 \\
\hline \multicolumn{2}{|c|}{ Viral: Non-viral } & $16: 13$ & $4: 10$ & $6: 3$ & $6: 0$ \\
\hline \multirow{2}{*}{$\begin{array}{l}\text { Tissue EGFR } \\
\text { expression } \\
\text { level (fM/mg } \\
\text { protein) }\end{array}$} & Viral & $54.7 \pm 27.8 \ddagger$ & $37 \pm 2.8 \%$ & $52.3 \pm 35.9 \dagger$ & $71.2 \pm 21.3 \dagger$ \\
\hline & $\begin{array}{l}\text { Non- } \\
\text { viral }\end{array}$ & $16.8 \pm 24.6$ & $6.3 \pm 1.9$ & $47.3 \pm 32.7$ & \\
\hline
\end{tabular}

Data are presented as mean $\pm \mathrm{SD}$, ratios \& numbers.

$\dagger$ : Significant difference versus WHO type 1

t: significant versus non-viral

Moreover, there was a positive significant correlation between the pathological WHO types and presence of viral infection, $(\mathrm{r}=0.568, \mathrm{p}=0.001)$ and the tissue expression levels of EGFR, $(\mathrm{r}=0.720, \mathrm{p}<0.001)$ and $\mathrm{a}$ positive significant correlation between tissue expression of EGFR and the presence of viral infection, $(r=0.595, P=0.001)$, (Table 4, Fig. 3a- c). Using ROC curve analysis to determine the specificity of both the presence of HPV infection and tissue expression of EGFR as determinant of the WHO pathological stage revealed that tissue expression of EGFR is more specific with $\mathrm{AUC}=0.731$ while just the presence of viral infection had an $\mathrm{AUC}=0.583$, (Fig. 4).

Table (4): Correlation coefficient " $r$ " between WHO types, presence of HPV infection and EGFR expression level

\begin{tabular}{|l|c|c|c|c|}
\hline \multirow{2}{*}{ Parameters } & \multicolumn{2}{|c|}{ EGFR expression level } & \multicolumn{2}{c|}{ Presence of HPV infection } \\
\cline { 2 - 5 } & "r" & $\mathbf{p}$ & "r" & $\mathbf{p}$ \\
\hline WHO types & 0.720 & $<0.001$ & 0.568 & $=0.001$ \\
\hline Presence of HPV infection & 0.595 & $=0.001$ & & \\
\hline
\end{tabular}



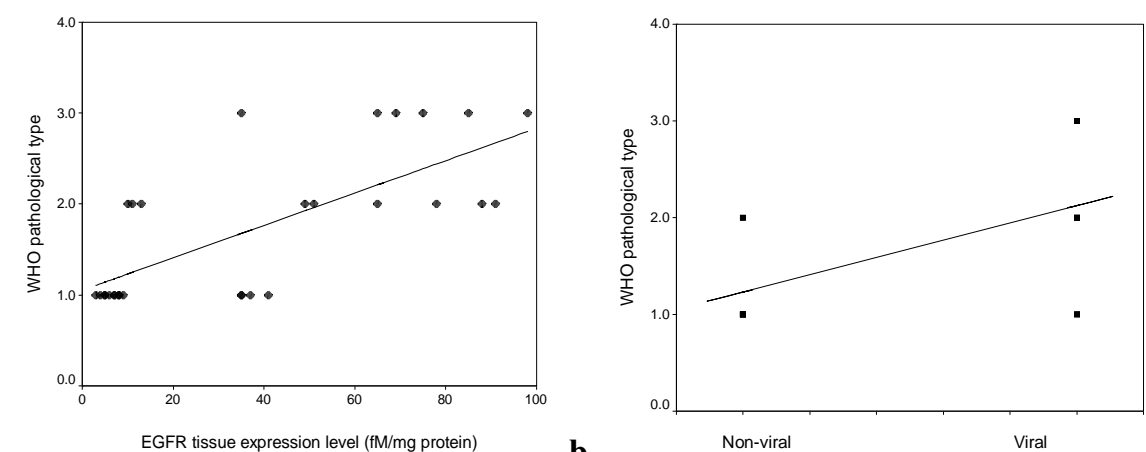

EGFR tissue expression level (fM/mg protein)

b

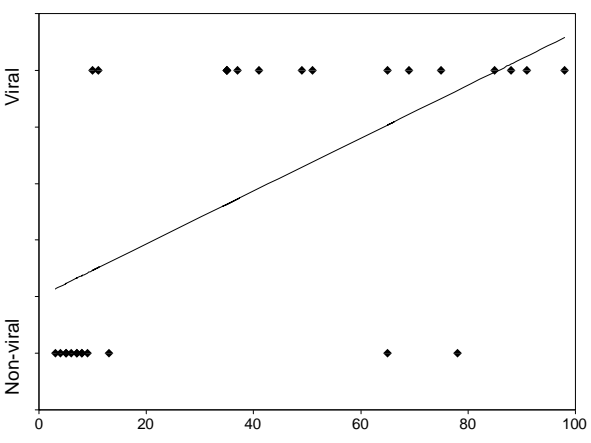

EGFR tissue expression level (fM/mg protein)

Fig. (3): Correlation between WHO pathological types, EGFR expression levels and presence of HPV infection

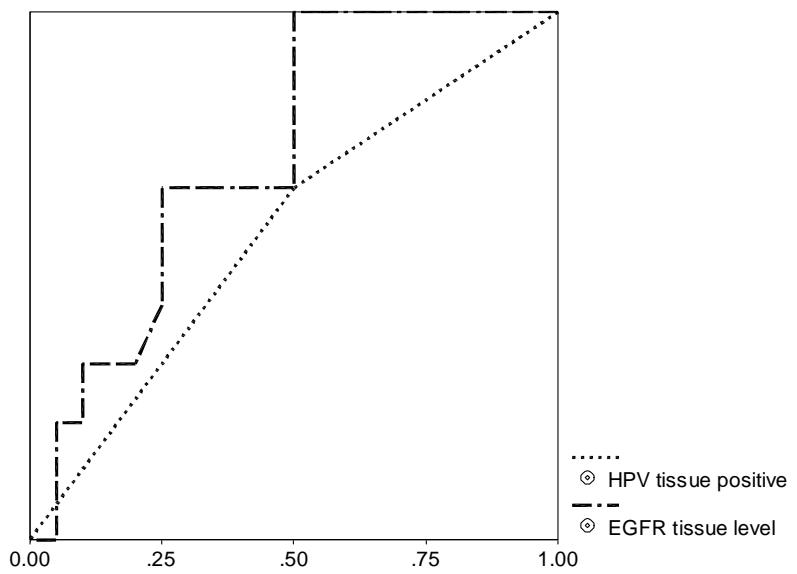

Fig. (4): ROC curve analysis for specificity for WHO stage 


\section{DISCUSSION}

Laryngeal carcinoma is the second most common type of head and neck cancer after skin cancer and accounts for $3 \%$ of total cancer risk ${ }^{(\mathbf{1 8})}$. The optimal primary treatment for laryngeal cancer is still a matter of international debate. The treatment proposed is often based on the extent of the disease, the clinician's experience and training, and geographic practice preferences ${ }^{(\mathbf{1 9})}$.

Radiotherapy with concurrent cisplatin is the standard alternative to total laryngectomy for patients with locally advanced laryngeal cancer and patients with complete response to induction chemotherapy in laryngeal carcinoma have a high probability of cure after hyperfractionation radiotherapy. However, hyperfractionation radiotherapy induces a high degree of toxicity that reduces the laryngeal function preservation rate and may jeopardize overall survival. Thus, a prerequisite of fundamental importance in dealing with the dilemma of treatment selection in patients with laryngeal cancer is the identification of unfavorable prognostic determinants that can serve as guidelines in addressing the treatment to the individual patient ${ }^{(\mathbf{2 0})}$.

Several lines of evidence support the EGFR as a molecular target for therapy of various SCC. First, overexpression of EGFR is one of the most common molecular alterations in SCC and the level of EGFR expression on HNSCC is elevated relative to expression on normal adjacent squamous mucosa in 83$100 \%$ of cases. Second, increased receptor content is often associated with increased production of ligands, such as transforming growth factor- $\alpha$, by the HNSCC ${ }^{(21)}$. Furthermore, treatment with EGFR-targeted therapy such as the chimeric monoclonal antibody cetuximab (C225) that binds competitively and with high affinity to the EGFR, such binding prevents stimulation of the receptor by endogenous ligands and results in inhibition of cell proliferation, enhanced apoptosis, and reduced angiogenesis, invasiveness and metastasis. Binding of cetuximab to the receptor also results in internalization of the antibodyreceptor complex which leads to an overall downregulation of EGFR expression. The EGFR is a prime target for new anticancer therapy that inhibits EGFR signaling and potentiates the effects of chemotherapy or radiation $^{(22)}$.

Moreover, Pivot et al. ${ }^{(23)}$ reported that EGFR determination appears to be a powerful prognostic parameter for patients with laryngeal and hypopharyngeal cancer treated by induction chemotherapy followed by exclusive radiotherapy and that laryngectomy seems to erase the prognostic impact of EGFR expression. They concluded that the obtained results prefer the use of EGFR targeting therapy for this category of patients.

Thus, the current study was designed to evaluate the frequency of HPV infection in patients with LSCC through identification of the viral DNA using PCR analysis and to determine the tissue levels of EGFR as a trial to find a relation between HPV infection, EGFR expression and 
clinicopathological findings in patients with LSCC.

The present study included 29 patients with LSCC with evident sex predilection to occur in males $(\mathrm{M}: \mathrm{F}$ ratio $=23: 6)$ and with higher percentage of smokers $(69 \%)$; thus illustrating the relationship between smoking and laryngeal carcinogenesis. These data go in hand with that reported by Alagić-Smailbegović et al. ${ }^{\text {(24) }}$ who reported a frequency of smokers of $93 \%$, however, such high frequency could be attributed to exclusion of female patients in their study and inclusion of only males in whom the frequency of both the disease and smoking is high.

PCR detected HPV-DNA in 16 $(55.2 \%)$ of specimens (viral specimens); 4 specimens of WHO type 1 and 12 specimens of WHO type 2 and 3 with a positive significant correlation between the presence of viral infection and the severity and aggressiveness of the cancer manifested as pathological stage. This result signified that a welldefined subset of LSCC may be etiologically linked to HPV infection and in such a subset of LSCCs, HPV infection would be an early event in a multistep process of laryngeal carcinogenesis and could address tumoral progression. This result agreed with those of Zhao et $\boldsymbol{a l}^{(25)}$ and Wang et al. $^{\text {(26) }}$ using PCR, they reported a rate of positive cases with HPV infection of $45.6 \%$ and $68 \%$ of their patients with laryngeal carcinoma, respectively. Also, Makowska et al. $^{(27)}$ reported that 10 out of 23 studied cases $(43.5 \%)$ of laryngeal carcinoma revealed presence of HPV DNA. Almadori et $\boldsymbol{a l}^{\mathbf{( 2 8 )}}$ reported a significant correlation between HPV infection and cyclin D1 gene amplification and suggested the involvement of HPV infection in laryngeal carcinogenesis and that HPV positive laryngeal cancers may constitute a different subset of tumors with a peculiar molecular pattern and thus with a different clinical behavior.

Also, Du et al. ${ }^{(29)}$ reported activation and nuclear localization of factors with the ability to inhibit cell death and to maintain and promote the growth of cells as NF- $\mathrm{BB}$ and sequestration of $\mathrm{p} 53$, a cell cycle progression inhibiting factor may play a role in the development of human laryngeal squameous cell carcinoma infected with HPV and GallegosHernández et al. ${ }^{(1)}$ found $50 \%$ of patients with laryngeal cancer patients were HPV positive.

Tissue expression levels of EGFR showed a significant increase in viral in comparison to non-viral cases irrespective of WHO pathological grade with significantly increased levels in specimens of WHO type 2 and 3 in comparison to specimens of WHO type 1 . These results illustrated the relationship between viral infection and increased expression of EGFR, a mechanism that may underlay the role imposed by HPV infection in pathogenesis of LSCC. These results agreed with that of Bentzen et al. ${ }^{(30)}$ who reported that EGFR expression rate was significantly associated with histologic grade and microvessel density of HNSCC and concluded that EGFR might play a key role in determining the proliferative cellular response to fractionated radiotherapy in HNSCC and with Chung et al. ${ }^{(31)}$ 
who analyzed EGFR status in 86 tumor samples from HNSCC patients by fluorescent in situ hybridization (FISH) and found that high EGFR gene copy number by FISH is frequent in HNSCC, is a poor prognostic indicator associated with worse progression-free and overall survival.

In support of the obtained results, there was a positive significant correlation between the tissue expression levels of EGFR and both the pathological WHO types of LSCC and with the presence of HPV infection. Using ROC curve analysis identified the level of EGFR expression as a specific determinant of LSCC severity manifested as the pathological stage. These findings go in hand with those of Penault-Llorca et al. $^{(\mathbf{1 0 )}}$ who reported that the level of EGFR expression is a prognosis factor for several tumors and appears to be an indicator of poor prognosis which might influence treatments of HNSCC. Also, the obtained results coincided with the results of the experimental work of Knecht et al. ${ }^{(32)}$ who investigated whether the addition of monoclonal antibodies against the EGFR could enhance the response rate of cisplatin, 5-FU and docetaxel and reported that the combination of cisplatin, 5-FU, docetaxel and the antibody resulted in highly significant complete tumor remissions, with no increased toxicity in the experimental animal. Also, Hitt et al. ${ }^{(21)}$ reported that in patients with oral SCC, EGFR status and an oral cavity location of the tumor have independent prognostic value in patients with advanced head and neck carcinoma treated with induction chemotherapy.
Furthermore, Psyrri et al. ${ }^{(11)}$ found that patients with oropharyngeal SCC associated with high tumor EGFR expression levels had a local recurrence rate of 58\% compared with $17 \%$ for patients with low EGFR tumor expression and that patients with high tumor EGFR levels had shorter disease-free survival compared with low expressors and concluded that in multivariate analysis adjusting for prognostic variables, high EGFR expression levels retained their prognostic significance. Pivot et al. ${ }^{(23)}$ studied potential prognostic factors were age, gender, performance status, primary tumor localization, $\mathrm{T}$ status, $\mathrm{N}$ status, tumor volume and tumoral EGFR level in patients with laryngeal and hypopharyngeal SCC and reported that EGFR determination appears to be a powerful prognostic parameter for patients treated by induction chemotherapy followed by exclusive radiotherapy.

It could be concluded that laryngeal infection with HPV may predispose to carcinogenesis through activation of certain growth factors as EGF and both were found significantly correlated with the aggressiveness of LSCC with the level of tissue expression of EGFR being a specific determinant of tumor aggressiveness manifested as pathologic stage.

\section{REFERENCES}

1. Gallegos-Hernández JF, Paredes-Hernández E, FloresDíaz R, Minauro-Muñoz G, Apresa-García $T$ \& Hernández-Hernández DM 
(2007): Human papillomavirus: association with head and neck cancer. Cir. Cir., 75(3): 151-5.

2. Syrjänen S (2005): Human papillomavirus (HPV) in head and neck cancer. J. Clin Virol.,32 (Suppl 1):S59-66.

3. Bologna-Molina RE, Castañeda-Castaneira RE, Molina-Frechero $\mathbf{N}$ \& PérezRodríguez E (2006): Human papilloma virus and its association with oral cancer. Rev. Med. Inst. Mex. Seguro. Soc., 44(2):147-53.

4. Mork J, Lie AK, Glattre E, Hallmans G, Jellum E, Koskela P, Moller B, Pukkala E, Schiller JT, Lehtinen M \& Dillner J (2001): Human papillomavirus infection as a risk factor for squamous-cell carcinoma of the head and neck N. Engl. J. Med., 344: 1125-31.

5. Boyer SN, Wazer DE \& Band $V$ (1996): E7 protein of human papilloma virus-16 induces degradation of retinoblastoma protein through the ubiquitinproteasome pathway. Cancer Res.,56(20):4620-4

6. Gillison ML \& Shah KV (2001): Human papillomavirusassociated head and neck squamous cell carcinoma: mounting evidence for an etiologic role for human papillomavirus in a subset of head and neck cancers. Curr. Opin. Oncol.,13(3):183-8.

7. Shiraki M, Odajima T, Ikeda T, Sasaki A, Satoh M, Yamaguchi A, Noguchi M, Nagai I \&Hiratsuka H (2005): Combined expression of p53, cyclin D1 and epidermal growth factor receptor improves estimation of prognosis in curatively resected oral cancer. Mod. Pathol., 18(11):1482-9.

8. Wight R, Paleri $\mathbf{V}$ \& Arullendran $P$ (2003): Current theories for the development of laryngeal carcinoma. Curr. Opin. Otolaryngol. Head Neck Surg., 11(2):73-7.

9. Herrero $\mathbf{R}$, Castellsague $\mathbf{X} \&$ Pawlita M (2003): Human Papillomavirus and Oral Cancer: The International Agency for Research on Cancer Multicenter Study. J. Nat. Cancer Inst., 95: 1772-83.

10. Penault-Llorca $F$, Durando $X$ \& Bay JO (2003): Prognostic value of epidermal growth factor receptor. Bull. Cancer, 90 Spec No: S192-6.

11. Psyrri A, Yu Z, Weinberger PM, Sasaki C, Haffty B, Camp R, Rimm D \& Burtness BA (2005): Quantitative determination of nuclear and cytoplasmic epidermal growth factor receptor expression in oropharyngeal squamous cell cancer by using automated quantitative analysis. Clin. Cancer Res., 11(16):5856-62.

12. AJCC (1988): Classification of Malignant Tumors. In: American Joint Committee on Cancer Manual for Staging of cancer, $3^{\text {rd }}$ ed., J.B. Lippincott, Philadelphia, 24-62.

13. Neel HB, Pearson GR \& Taylor WF (1983): Application of Epstein Barr virus serology to the diagnosis and staging of North American patients with 
nasopharyngeal carcinoma. Otolaryngol. Head Neck Surg., 91: 255 .

14. Battaglia F, Polizzi G, Scambia G, Rossi S, Benedetti Panici P, Iacobelli S, Crucitti F \& Mancuso S (1988): Receptors for epidermal growth factor and steroid hormones in human breast cancer. Oncology, 45: 424-7.

15. Almadori G, Cadoni G, Cattani P, Scarano E, Ottaviani F, Paludetti $G$ \& Maurizi M (1996): Detection of human papillomavirus DNA in laryngeal squameous cell carcinoma by polymerase chain reaction. Eur. J. Cancer, 32A: 783-8.

16. Resnick RM, Cornnelissen MT, Wright DK, Eichinger GH, Fox HS, Ter Shegget J \& Manos MM (1990): Detection and typing of human papillomavirus in archival cervical cancer specimens by DNA amplification with consensus primers. J. Natl. Cancer Inst. (Bethesda), 82: 1477-84.

17. Van Den Brule AJC, Mejer CJ, Bakels V, Kenemans $P$ \& Walboomers JM (1990): Rapid detection of human papillomavirus in cervical scrapes by combined general primer-mediated and typespecific polymerase chain reaction. J. Clin. Microbiol., 28: 2739-43.

18. Rzewnicki I, Luczaj J, Olszewska E \& Lachowicz M (2002): Epidemiologic analysis of patients with laryngeal and hypopharyngeal cancer treated in the Department of Otolaryngology in Białystok from 1986-1999. Otolaryngol Pol.,56(1):19-21.

19. Johansen LV, Overgaard CG \& Overgaard J (2003): Laryngeal carcinoma: multivariate analysis of prognostic factors in 1252 consecutive patients treated with primary radiotherapy. Acta Oncol.,42:771-8.

20. Majem M, Mesia R, Mañós M, Gomez J, Galiana R, Cardenal F, Juan A, Montes A, Perez FJ, Nogues J \& Llluch JR (2006): Does induction chemotherapy still have a role in larynx preservation strategies? The experience of Institut Catala d'Oncologia in stage III larynx carcinoma. Laryngoscope, 116(9):1651-6.

21. Hitt R, Ciruelos E, Amador ML, Benito A, Sanchez JJ, Ballestin $\mathbf{C} \&$ Cortes-Funes $\mathbf{H}$ (2005): Prognostic value of the epidermal growth factor receptor (EGRF) and p53 in advanced head and neck squamous cell carcinoma patients treated with induction chemotherapy. Eur. J. Cancer, 41(3):453-60.

22. Harding $\mathbf{J} \&$ Burtness $B$ (2005): Cetuximab: an epidermal growth factor receptor chemeric human-murine monoclonal antibody. Drugs Today (Barc)., 41(2):107-27.

23. Pivot $X$, Magné $N$, Guardiola E, Poissonnet G, Dassonville O, Francoual M, Formento JL, Bensadoun RJ, Demard F, Schneider M \& Milano G (2005): Prognostic impact of the epidermal growth factor receptor levels for patients with larynx 
and hypopharynx cancer. Oral Oncol., 41(3):320-7.

24. Alagić-Smailbegović $\mathbf{J}$, Kapidzić A, Sutalo K, Resić M \& Hadzić E (2004): Incidence of malignant tumors of larynx and their treatment. Bosn. J. Basic Med. Sci., 4(4):25-7.

25. Zhao S, Lu S \& Fei S (1999): Detection of human papillomavirus in Chinese laryngeal carcinoma with digoxigenin labelled probe prepared by PCR. Lin. Chuang. Er. Bi. Yan. Hou. Ke. Za. Zhi., 12(4): 153-5.

26. Wang L, Zhang $T$ \& Zhang $F$ (1999): Study on the association between squamous cell carcinoma of larynx and HPV subgene by PCR. Zhonghua. Er. Bi. Yan. Hou. Ke. Za. Zhi., 34(2):106-7.

27. Makowska W, Malejczyk M, Kapiszewska D, Nyckowska J, Wojcikiewicz E \& Wroblewska B (2001): Human papillomavirus (HPV) in the laryngeal carcinoma. Otolaryngol. Pol., 55(3): 263-6.

28. Almadori G, Galli J, Cadoni G, Bussu F \& Maurizi M (2002): Human papillomavirus infection and cyclin D1 gene amplification in laryngeal squameous cell carcinoma: biologic function and clinical significance. Head Neck, 24(6): 597-604.

29. Du J, Chen GG, Vlantis AC, Xu H, Tsang RK \& van Hasselt AC (2003): The nuclear localization of NFkappaB and p53 is positively correlated with HPV16 E7 level in laryngeal squameous cell carcinoma. J. Histochem. Cytochem., 51(4): 533-9.

30. Bentzen SM, Atasoy BM, Daley FM, Dische S, Richman PI, Saunders MI, Trott KR \& Wilson GD (2005): Epidermal growth factor receptor expression in pretreatment biopsies from head and neck squamous cell carcinoma as a predictive factor for a benefit from accelerated radiation therapy in a randomized controlled trial. J. Clin. Oncol., 23(24):5560-7.

31. Chung CH, Ely K, McGavran L, Varella-Garcia M, Parker J, Parker N, Jarrett C, Carter J, Murphy BA, Netterville J, Burkey BB, Sinard R, Cmelak A, Levy S, Yarbrough WG, Slebos RJ, Hirsch FR (2006): Increased epidermal growth factor receptor gene copy number is associated with poor prognosis in head and neck squamous cell carcinomas. J. Clin. Oncol., 24(25):4170-6.

32. Knecht R, Peters S, Solbach C, Baghi M, Gstottner W \& Hambek M (2003): EGFR antibody-supplemented TPEchemotherapy. Preclinical investigations to a novel approach for head and neck cancer induction treatment. Anticancer Res., 23(6C): 478995. 


\title{
معدل استخراج الأنسجة لمستقبل عامل نمو البشرة كمتنبئ لتفاقم أورام البهام الحنجرة المصاحبة للعدوى بفيروس البابيلوما البشرى
}

\author{
ثناء حامد، مسعد عودة، ابهان بدر†، إبراهيم راجح*، بكر الثافعي راس ***،

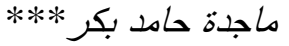

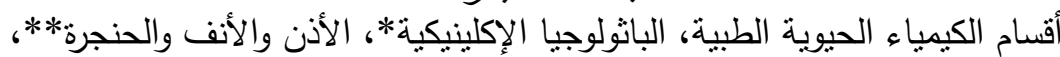 \\ الباثولوجي *** -كلية الطب - جامعتى بنها والمنوفية الطان
}

صمدت هذه الدراسة لتقييم معدل العدوى بفيروس البابيلوما البشرى في مرضى أورام الحنجرة من خلال

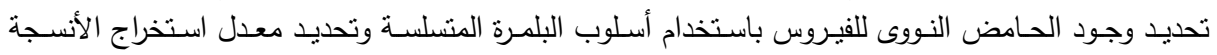

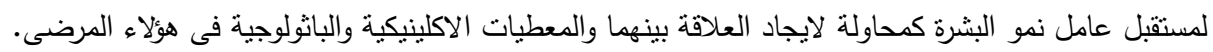

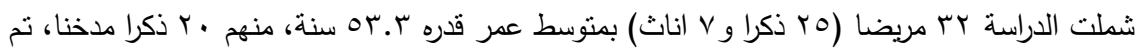

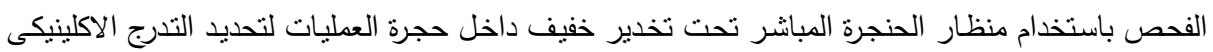

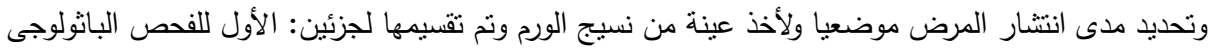

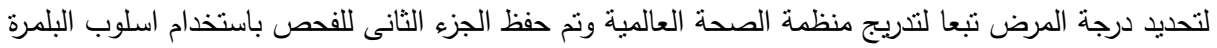

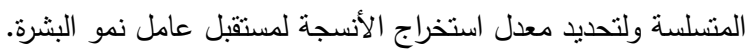

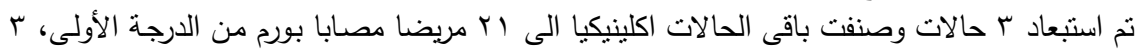

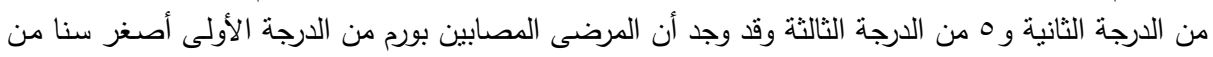

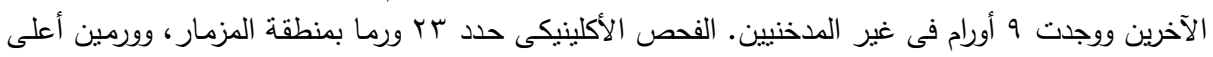

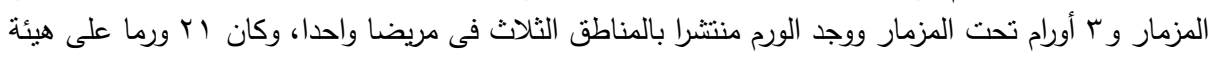

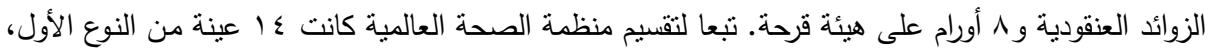

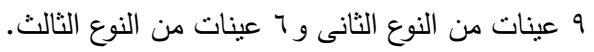

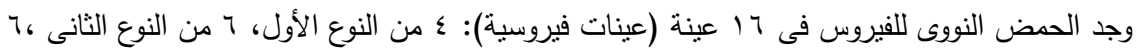

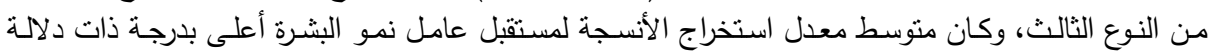

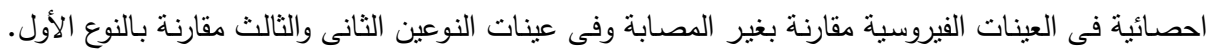

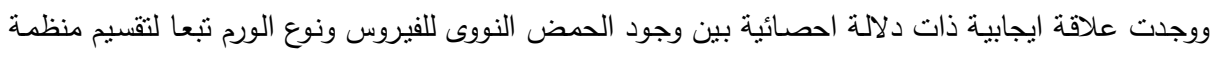

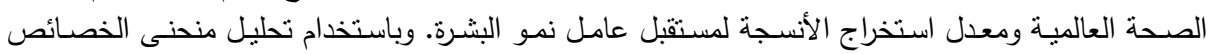

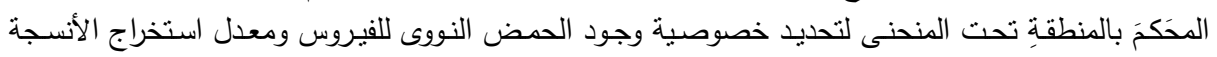

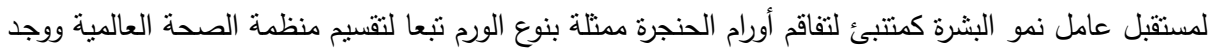

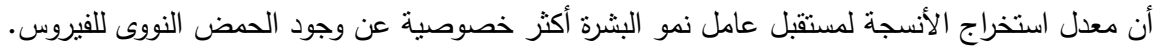

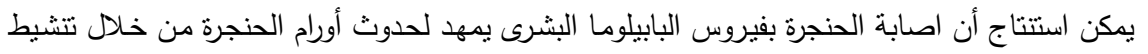

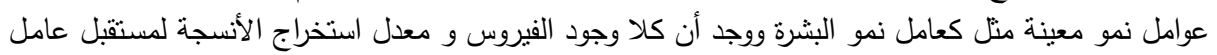

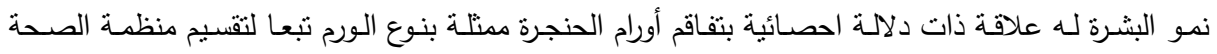

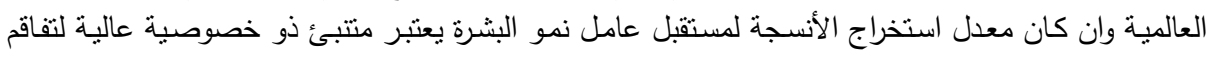
أورام الحنجرة. 